\title{
Sustainable Earthen Architecture
}

\section{Udržitelná hliněná architektura}

\section{Lenka Bažík}

Ústav stavitelství, Fakulta architektury, Vysoké učení technické v Brně školitel: doc. Ing. Ivana Žabičková, CSc.

\begin{abstract}
Sustainable architecture must meet environmental, sociocultural and economic criteria. Based on analysis and interpretation, this paper explores to what extent earthen building material meets these categories. Earth is a traditional, environmentally friendly, recyclable material that has a positive effect on human health. The aim of this paper is to evaluate earthen building material in terms of sustainable architecture.
\end{abstract}

KEYWORDS: sustainable architecture, earthen building material, environmentally friendly architecture

\begin{abstract}
ABSTRAKT: Trvale udržitelná architektura má splňovat kritéria environmentální, sociálně-kulturní a ekonomická. Tento článek zkoumá na základě analýzy a interpretace, do jaké míry hliněný stavební materiál naplňuje zmíněné kategorie. Nepálená hlína je materiál tradiční, šetrný k životnímu prostředí, recyklovatelný a má pozitivní vliv na zdraví člověka. Cílem článku je zhodnotit hliněný stavební materiál z hlediska trvale udržitelné architektury.
\end{abstract}

KLÍČOVÁ SLOVA: trvale udržitelná architektura, nepálená hlína, ekologická architektura 


\section{Úvod}

Trvale udržitelný rozvoj je významné téma posledních let, které zasahuje téměř do všech odvětví společnosti. Stavební průmysl spotřebuje celosvětově $36 \%$ energie a vyprodukuje 39 \% emisí oxidu uhličitého $\left(\mathrm{CO}_{2}\right)$ (Abergel et al. 2017), tedy více než jakékoliv jiné odvětví.

Udržitelné budovy jsou charakterizovány nižší spotřebou energie, materiálů, vody a dalších zdrojů a využíváním takových materiálů, které mají menší negativní dopady na životní prostř̌edí. Může se zdát, že nejekologičtější jsou budovy, které mají solární panely na střeše, větrné turbíny atd. Je to ale přesně naopak. Nejšetrnější k životnímu prostředí jsou budovy zpravidla tiché a nenáročné, které chytře využívají denní osvětlení, přirozenou ventilaci a další pasivní formy řízení vnitřního prostředí (Bothwell 2015).

Hlína je jeden z nejstarších stavebních materiálů na světě. Z nepálené hlíny se stavělo již před deseti tisíci lety, na našem území se používání hlíny ve stavebnictví rozšírílo především v 17. a 18. století (Žabičková 2003). Přitom je jasné, že udržitelnost stavebních materiálů závisí na místním kontextu (Caldera et al. 2011). Dnes se na našem území nachází tisíce staveb, kde je použita nepálená hlína, a tento počet neustále roste. Zvýšenou poptávku po prrírodních materiálech lze mimo jiné přičíst i zájmu lidí o vlastní zdraví.

Cílem článku je na základě analýzy a interpretace zjistit, zda je hliněná architektura trvale udržitelná a na základě jakých kritérií lze tuto udržitelnost posuzovat.

\section{Kritéria hodnocení trvale udržitelné architektury $\mathrm{z}$ hlediska použité- ho stavebního materiálu}

Výzkum trvale udržitelné hliněné architektury byl proveden analýzou a interpretací dostupných zdrojů poznání, především analýzou odborné literatury, celosvětových certifikací udržitelné výstavby a obecného poznání. Analýza zdrojů se kromě obecných principů trvale udržitelné architektury musela zúžit na takové odvětví, které souvisí se stavebním materiálem a kde tedy lze nepálenou hlínu objektivně hodnotit z hlediska trvalé udržitelnosti.

Celosvětově nejrozšířenějšími systémy pro posuzování udržitelnosti výstavby jsou BREEAM a LEED, k dalším pak patří například Minergie, Green Building Standards a v neposlední řadě český SBToolCZ. 
BREEAM je původem britská certifikace, jejíž název v překladu znamená „metoda environmentálního hodnocení vyvinutá organizací BRE“ a která byla poprvé publikována již v roce 1990. BREEAM hodnotí stavby v následujících kategoriích: management, zdraví a pohoda, energie, doprava, voda, materiály, odpad, využití půdy a ekologie, znečištění a inovace (BREEAM 2018).

O deset let starší je americký systém hodnocení budov LEED, v překladu „vedení v oblasti energetiky a životního prostředí“. Certifikace LEED posuzuje kritéria ekologie, zdraví, vodní zdroje, biodiverzita, recyklace materiálů, ekonomika a sociální aspekty (LEED 2018).

V České republice existuje od roku 2010 certifikace udržitelnosti staveb SBToolCZ, která na rozdíl od světových nástrojů plně podporuje české prostředí, a to z hlediska klimatu, stavebních materiálů a legislativy. SBToolCZ hodnotí kritéria environmentální, sociálně-kulturní a ekonomická (Vonka 2011).

Na základě analýzy výše zmíněných kritérií, která se posuzují u trvale udržitelné výstavby, vyšlo najevo, že trvale udržitelnou hliněnou architekturu lze zkoumat v následujících kategoriích: znečištění životního prostředí, vliv na zdraví a sociální aspekty.

\section{Znečištění životního prostředí}

Stavební průmysl způsobuje 40 \% znečištění naší planety z toho $11 \%$ se týká stavebních materiálů (Abergel et al. 2017). Emise uhlíku vznikají při výrobě, distribuci i aplikaci stavebních materiálů. Největší znečištění vzniká při těžbě a zpracování materiálu, toto znečištění lze eliminovat používáním př́rodních neupravovaných zdrojů a minimalizováním práce těžké techniky. Dalším bodem je pak využínání místních materiálů, a tedy snižování emisí z dopravy.

Je také důležité počítat s energií vydávanou na údržbu a opravy. Obecně platí, že čím jednodušší je řešení stavby, tím snadnější je také oprava a údržba. Znečištování životního prostředí stavebním materiálem nastává také po ukončení životnosti stavby. Je nezbytné, aby bylo možné použité materiály jednoduše navrátit do př́rody nebo bez náročných úprav opětovně použít k jinému účelu.

\section{Vliv na zdraví}

Stavební materiály obklopující uživatele vnitřních prostor mají přímý vliv na jejich komfort, bezpečnost a zdraví. Mikroklima budov, ovlivnitelné stavebními materiály, lze hodnotit na základě několika parametrů - vlhkost a čistota vzduchu, vizuální komfort, akustika a tepelná pohoda. 
Velmi důležitá je zdravotní nezávadnost materiálu, tedy to, zda během výstavby a po dobu své životnosti materiál neznečištuje ovzduší a neškodí lidskému zdraví.

\section{Sociální aspekty}

Poslední kategorií, kterou materiál stavby ovlivňuje, je kulturní a sociální prostředí. Před velkou průmyslovou revolucí bylo naprosto běžné stavět z místních materiálů. Znalosti a dovednosti potřebné pro stavbu např. vlastního domu se předávaly z generace na generaci, což podporovalo rozvoj místních komunit. Dnešní trend, že je stavební trh ovládán několika velkými výrobci stavebních materiálů, je oproti tomu neudržitelný.

Design budovy by měl vždy vycházet z klimatických podmínek, sociálního prostředí a místní tradice, tyto kvality dřive běžně reflektovala regionální lidová architektura. Pro udržitelnou architekturu je přitom důležité použivání místních obnovitelných materiálů.

\section{Hodnocení trvale udržitelné hliněné architektury}

Na základě posouzení zvolených kritérií lze tedy hodnotit hliněný stavební materiál.

\section{Hlína a znečištění životního prostředí}

Základem hliněného stavebního materiálu je jílové pojivo, které je nositelem soudržnosti. Jílová ložiska se jen na našem území nacházejí na 124 místech, mimoto je jíl v určitém množství obsažen ve všech soudržných zeminách. Při využití místních zdrojů hlíny se tedy $\mathrm{v}$ př́ípadě použití prefabrikovaného materiálu eliminuje značná část emisí, která by připadla na dopravu. Hliněný stavební materiál lze zpracovávat ručně i pomocí techniky, záleží na typu konstrukce a volbě pracovní síly. Výroba hliněného stavebního materiálu však není energeticky náročná, a proto ho lze hodnotit velmi pozitivně.

Pokud je hlína použitá ve stavbě bez umělých přísad a bez poškození např. plísněmi, je recyklovatelná. Lze ji navrátit do přírody nebo z ní vytvořit novou směs a použít ji znovu. $\mathrm{V}$ této kategorii hliněný materiál obstojí.

\section{Hlína a vliv na zdraví}

Významnou vlastností jílu je schopnost absorbovat a uvolňovat vlhkost (Minke 2007). Díky tomu hlína použitá na povrchu dokáže regulovat vlhkost v místnosti, tedy udržovat ji v takovém rozmezí, které je člověku nejpř́ijemnější. $\mathrm{K}$ tomuto přirozenému 
jevu není potřeba žádné další technologické zařízení. Z hlediska akustiky se nepálená hlína blíží hodnotám pálené cihly. Vizuální komfort je subjektivní vjem, proto ho nelze jednoznačně hodnotit. Nepálená hlína má velmi dobré akumulační schopnosti, při hodnocení kritéria tepelné pohody obstojí. Hlínu lze velmi kladně hodnotit také z hlediska čistoty prostředí a zdravotní nezávadnosti (Janík et al. 2016).

\section{Hlína a sociální aspekty}

Nepálenou hlínu používají při novostavbě převážně lidí nadšení pro zdravého bydlení, kteří si mezi sebou předávají znalosti a zkušenosti. Hlína tedy alespoň v malé míře funguje jako akcelerátor vzniku místních komunit. Pro použití hlíny na stavbě je důležitá dobrá znalost nejen materiálu, ale i klimatických podmínek a sociálního zázemí, přičemž je důležité pochopit kontext místa pro správnou aplikaci materiálu.

\section{Závěr}

Podle kritérií BREEAM může stavební materiál ovlivnit až z 55 \% celkové hodnocení udržitelnosti stavby. Dle LEED až z $60 \%$, podle SBToolCZ až z $61 \%$. Je tedy jasné, že stavební materiál je významným faktorem trvalé udržitelnosti architektury.

Na základě zvolených kritérií a jejich posouzení u hliněného stavebního materiálu je možné považovat hliněnou architekturu za trvale udržitelnou za určitých podmínek. Hliněný stavební materiál by měl být ve stavbách použiván bez umělých př́sad, aby byla možná následná recyklace. Z výzkumu také vyplývá, že hlína by měla být ve stavbě použita spíše tam, kde má opodstatnění. Tedy v oblastech s vhodnou stavební hlínou, kde má kulturní tradici.

Tento článek by měl sloužit jako podklad pro další výzkum hliněného stavebního materiálu a jeho potenciálu pro využití v současné udržitelné výstavbě.

\section{Použitá literatura}

ABERGEL, Thibaut, Brian DEAN a John DULAC, 2017. Towards a zero-emission, efficient, and resilient buildings and construction sector [online]. B.m.: United Nations Environment Programme. Dostupné z: http://www.worldgbc.org/sites/ default/files/UNEP 188_GABC_en \%28web\%29.pdf

BOTHWELL, Keith, 2015. Sustainable architecture. In: Michael REDCLIFT a Delyse SPRINGETT, ed. Routledge International Handbook of Sustainable Development [online]. s. 147-163. ISBN 0078701406. Dostupné z: doi:10.7910/DVN/PZB01G 
BREEAM, 2018. www.breeam.com [online]. Dostupné z: www.breeam.com

CALDERA, Carlo, Andrea BOCCO, Simonetta PAGLIOLICO, E.C.M. VALCÁRCEL, A.r. BERORELLO a Irene CALTABIANO, 2011. Natural materials and building techniques for social sustainability [online]. Dostupné z: https://didattica.polito. it/pls/portal30/sviluppo.dotto.download_file?p_id=1911

JANÍK, R., M. PAJTÁŠOVÁ, E. JÓNA, D. ONDRUŠOVÁ a V. JANÍKOVÁ, 2016. Detoxikácia zložiek životného prostredia pomocou fylosilikátov. In: Luboš SIBILLA a Zdeněk VEJPUSTEK, ed. Zdravé domy 2016. B.m.: Sdružení hliněného stavitelství z. s., s. 101-102.

LEED, 2018. new.usgbc.org/leed [online]. Dostupné z: https://new.usgbc.org/leed

MINKE, Gernot, 2007. Building with Earth: Design and Technology of a Sustainable Architecture. Basel: Birkhäuser. ISBN 9788578110796.

VONKA, Martin, 2011. Metodika SBToolCZ - Manuál hodnocení bytových staveb ve fázi návrhu.

ŽABIČKOVÁ, Ivana, 2003. Hliněné stavby. B.m.: ERA. ISBN 978-80-86517-21-6. 